\title{
Melatonin as a potential inhibitory agent in head and neck cancer
}

\author{
Chia-Ming Yeh ${ }^{1, *}$, Shih-Chi Su ${ }^{2,}{ }^{*}$, Chiao-Wen Lin ${ }^{3,4}$, Wei-En Yang ${ }^{1,5}$, Ming-Hsien Chien ${ }^{6}$, \\ Russel J. Reiter ${ }^{7}$ and Shun-Fa Yang ${ }^{1,5}$ \\ ${ }^{1}$ Institute of Medicine, Chung Shan Medical University, Taichung, Taiwan \\ ${ }^{2}$ Whole-Genome Research Core Laboratory of Human Diseases, Chang Gung Memorial Hospital, Keelung, Taiwan \\ ${ }^{3}$ Institute of Oral Sciences, Chung Shan Medical University, Taichung, Taiwan \\ ${ }^{4}$ Department of Dentistry, Chung Shan Medical University Hospital, Taichung, Taiwan \\ ${ }^{5}$ Department of Medical Research, Chung Shan Medical University Hospital, Taichung, Taiwan \\ ${ }^{6}$ Graduate Institute of Clinical Medicine, Taipei Medical University, Taipei, Taiwan \\ ${ }^{7}$ Department of Cellular and Structural Biology, The University of Texas Health Science Center, San Antonio, TX, USA \\ *These authors contributed equally to the work
}

Correspondence to: Russel J. Reiter, email: reiter@uthscsa.edu

Shun-Fa Yang, email: ysf@csmu.edu.tw

Keywords: melatonin, head and neck cancers, metastasis, matrix metalloproteinase

Received: June 06, 2017 Accepted: July 26, $2017 \quad$ Published: August 09, 2017

Copyright: Yeh et al. This is an open-access article distributed under the terms of the Creative Commons Attribution License 3.0 (CC BY 3.0 ), which permits unrestricted use, distribution, and reproduction in any medium, provided the original author and source are credited.

\section{ABSTRACT}

Melatonin is a molecule secreted by the pineal gland; it is an important regulator of sleep and circadian rhythms. Through multiple interrelated mechanisms, melatonin exhibits various inhibitory properties at different stages of tumor progression. Many studies have explored the oncostatic effects of melatonin on hormone-dependent tumors. In this review, we highlight recent advances in understanding the effects of melatonin on the development of head and neck cancers, including molecular mechanisms identified through experimental and clinical observations. Because melatonin exerts a wide range of effects, melatonin may influence many mechanisms that influence the development of cancer. These include cell proliferation, apoptosis, angiogenesis, extracellular matrix remodeling through matrix metalloproteinases, and genetic polymorphism. Thus, the evidence discussed in this article will serve as a basis for basic and clinical research to promote the use of melatonin for understanding and controlling the development of head and neck cancers.

\section{INTRODUCTION}

Head and neck cancers constitute the sixth most common malignancy in the world. Most head and neck cancers occur in the epithelial lining of the oral cavity, hypopharynx, larynx, and oropharynx. Squamous cell carcinoma is the most frequent type, accounting for approximately $90 \%$ of all head and neck cancers. Approximately $50 \%$ of all head and neck cancers occur in the oral cavity $[1,2]$. Alcohol and tobacco use are major risk factors for most head and neck cancers; studies have revealed that the incidence of head and neck cancers is higher in regions with high rates of alcohol and tobacco consumption $[3,4]$. Also, experimental and clinical data indicate that human papillomavirus infection is also related to the development of head and neck cancers $[5,6]$. The overall 5-year survival for head and neck cancers is approximately $50 \%$; this statistic has not changed much in the past few decades.

Melatonin

Melatonin, chemically named N-acetyl-5methoxytryptamine, was discovered in the bovine pineal gland by Lerner in 1958 [7]. Since its discovery, melatonin has been extensively studied, and numerous benefits have been reported (Figure 1). Melatonin is widely distributed in bacteria, unicellular organisms, algae, plants, invertebrates, and in many organs of vertebrates [8-11]. Its production has also been documented in nonvertebrates 
and plants that lack a pineal gland $[8,12]$. In mammals, melatonin is a derivative of tryptophan. It is synthesized in the pineal gland and rhythmically secreted into the blood [13-15] and into the cerebrospinal fluid (CSF) $[16,17]$. The production of melatonin begins at night during darkness; in humans, melatonin reaches maximal concentration near the middle of the dark period [13].

Melatonin is a molecule with pleiotropic functions; it is involved in regulating the circadian rhythms of physiological functions, including blood pressure, seasonal reproduction, and sleep timing [18-21]. Various receptor subtypes are available for melatonin binding and activation. Studies have demonstrated that membrane melatonin receptors are on perhaps all cells including retina, brain, suprachiasmatic nucleus, pituitary gland, ovary, cerebral artery, peripheral artery, kidney, pancreas, fat, and immune cells [22-24]. Among several signaling mechanisms, melatonin actions are activated through high-affinity G protein-coupled receptors (GPCRs), including the MT1 and MT2 [25-27]; they have amino acid sequences that have $60 \%$ homology and different chromosomal localization [28, 29]. These melatonin receptors have potential glycosylation sites at their $\mathrm{N}$-terminus regions and have casein kinase 1 and 2, protein kinase $\mathrm{A}$, and protein kinase $\mathrm{C}$ phosphorylation sites, which may be involved in the regulation of receptor function, as evidenced in other GPCRs [30]. In addition to the well described membrane melatonin receptors, melatonin has binding sites in the nucleus [31, 32] and couples with calmodulin and quinone reductase 2 in the cytosol [33, 34]. Major receptor-mediated actions of melatonin include the regulation of circadian rhythms including sleep [19, 35] as well as other actions such as anti-cancer and anti-inflammatory actions [36-47].

In normal cells, melatonin and its derivatives are powerful free radical scavengers and multi-faceted antioxidants [11, 48, 49]. Melatonin executes its direct free radical scavenging actions via non-receptor-mediated mechanisms. Melatonin reduces oxidative stress that is associated with many diseases, including optic neuritis, myocardial ischemia and neurological disease [50-53]. Compared with other antioxidants, melatonin has an equal or superior ability to protect tissues from oxidative injury even when compared with synthetic mitochondria-targeted antioxidants [54]. One difference between melatonin and other free radical scavengers is its amphiphilicity, which allows melatonin to distribute throughout the subcellular environment although in differing concentrations among organelles [55]. Furthermore, melatonin is estimated to detoxify up to 10 free radicals through the AFMK pathway, thus increasing its effective concentration [56]. As noted above, melatonin also interacts with the detoxifying enzyme, quinone reductase 2 [34]. Although the mechanism of this interaction is unclear, this coupling may be related to the regulation of cell redox status [57]. Also, the interaction between melatonin and calmodulin may be involved in antioxidant signaling and other signaling processes that reduce the oxidative burden [33]. In addition to directly scavenging toxic oxygen-based reactants, melatonin also indirectly limits oxidative damage by stimulating a variety of antioxidant enzymes which remove free radicals before they damage essential molecules [58-61].

Oxidative stress is defined as the imbalance between an organism's cellular production of oxidative agents, such as reactive oxygen species (ROS), and the organism's antioxidant capacity, ROS participate in many different cellular processes during physiological and pathologic reactions [62].

In cancer cells, melatonin functions as a conditional pro-oxidant [63-65]. For example, Wolfler et al. [65] showed that melatonin stimulates ROS generation and causes Fas-induced apoptosis in human leukemic cells. Osseni et al. [66] also reported that melatonin can be both anti-oxidant and pro-oxidant in a human HepG2 liver cell line. In cervical cancer cells, Pariente et al. [67] reported that melatonin enhances cisplatin-induced cytotoxicity and apoptosis due to ROS overproduction. Moreover, Um et al. [68] demonstrated that melatonin attenuates oxaliplatin-induced apoptosis and anti-oxidant action in renal carcinoma Caki cells.

ROS production promotes the release of inflammatory mediators, including the activation of redoxregulated transcription factors, such as $\mathrm{NF}-\kappa \mathrm{B}$, to produce cytokines by activating the intracellular inflammatory signaling pathways [69]. Melatonin scavenges a variety free radicals in body fluids, cells and in vitro [70-72]. These effects enable melatonin to reduce the level of ROS and decrease oxidative pathologies such as seen in atherosclerosis, neurodegenerative diseases, hypertension, ischemia, and cancer [73-75].

Clinical evidence that has accumulated in the last two decades suggests that melatonin inhibits the growth of many cancers, including cervical cancer, ovarian cancer, breast cancer, and colon cancer [76-79]. The drop in melatonin that occurs during aging correlates with immunosenescence, neurodegenerative disorders, and cancer. Moreover, breast cancer cell proliferation is higher during the daytime (when melatonin levels are low) than during the night (when melatonin levels are high). Thus, the age-associated reduction of melatonin with advancing age may promote the proliferation of breast cancer as well as other cancer types [80].

Melatonin released into the oral cavity by saliva may have protective effects on many oral disorders, such as herpes viral infections and Candida infection, periodontal diseases, xerostomia, local inflammatory processes, oral ulcers, and oral cancer [81, 82]. Moreover, Ortiz et al. [83] reported that melatonin gel applied in the oral cavity can reduce the development of erythema and prevents ulcer formation; therefore, it is a potential preventive therapy for radiotherapy-induced oral mucositis. Of melatonin's various effects on oral disorders, the most widely studied is its role in periodontal disease, which is related to the 
anti-inflammatory and antioxidant properties of melatonin. In addition, radical scavengers, such as melatonin, reduce oxidative damage in in vivo and in vitro in head and neck cancers [84].

This article focuses on the role of melatonin in the treatment of head and neck cancers (Figure 2). Since head and neck cancers are among the list of life-threatening diseases with poor survival rates, an agent that retards or controls the occurrence of these tumors is in need of identification. Therefore, we focus the effects of melatonin on the development of head and neck cancers, including molecular mechanisms identified through experimental and clinical observations (Table 1).

\section{Melatonin: antiproliferative and pro-apoptotic actions in head and neck cancer}

The difference between head and neck cancer cells and normal cells is that head and neck cancer cells exhibit uncontrolled and sustainable growth. Normal cells regulate growth, division, and the cell cycle through complex cell growth messages (growth-promoting signals) that maintain a constant number and size of cells. Most head and neck cancer cells are over-reliant on specific signaling pathways (signaling transduction pathways) which promote cancer cell proliferation [85]. Aberrations in the critical pathways that regulate cell survival and cell proliferation are necessary for establishing all tumors [86]. The deregulation of cell proliferation and inhibition of apoptosis are common mechanisms involved in the development of all cancers $[38,87,88]$. Therefore, identifying the difference between tumor cells and normal cells and the appropriate use of this information are key issues in cancer treatment [89].

Empirical evidence unequivocally documents that toxic oxygen derivatives influence the balance between cell proliferation and apoptosis. If the mechanisms of apoptosis are overwhelmed, cell proliferation may predominate leading to tumor formation. Thus, radical scavengers such as melatonin may regulate the proliferation of head and neck cancers through the reduction of oxidative damage [84]. Multiple proliferative signals affect apoptosis programming by inducing Alternative reading frame protein (ARF), an alternate product of the INK4a locus, one of its functions is to trigger the upregulation of $\mathrm{p} 53$ by inhibiting MDM-2 [90, 91].

Apoptosis, a type of programmed cell death, is an important mechanism that normally occurs in all tissues. This mechanism is important for ridding tissues from damages on diseased cells. Apoptosis often also occurs during aging and development and acts as a homeostatic mechanism for maintaining the stability of the cell population in the tissues. It is also a defense mechanism for the immune response and for cells damaged by noxious agents or disease [92]. Although various physiological and pathological stimuli or conditions can trigger apoptosis, not all cells die from the same stimulus. Drugs or radiation for cancer chemotherapy also cause

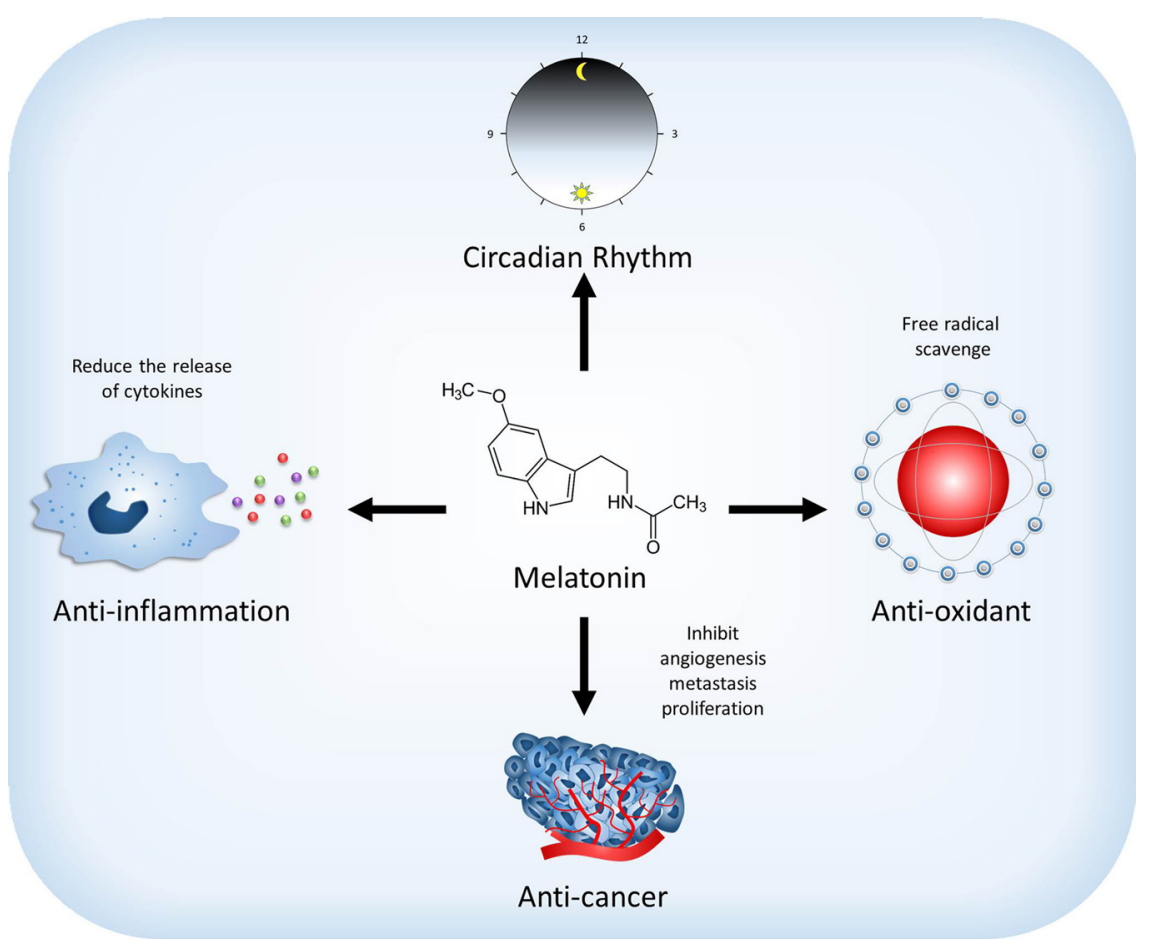

Figure 1: Effect of melatonin on the physiological and pathological functions. Melatonin regulates sleep and circadian rhythms. Moreover, melatonin also has anti-oxidant and anti-inflammation abilities to scavenge free radical and reduce the release of cytokines. Melatonin may reduce the development of cancer through affecting the mechanism of angiogenesis, metastasis and proliferation. 
DNA damage in some cells, which triggers apoptosis through a p53-dependent pathway [93, 94]. Cell apoptotic programs involve either the intrinsic or extrinsic pathway, as distinguished by the source of the death signal and initiator caspases involved [95]. The intrinsic apoptosis is a response to internal damage (e.g., mitochondrial stress or chromosomal defects) with the activation of caspase 9, whereas the extrinsic apoptotic pathway is mediated through membrane-bound death receptors (e.g., FAS or tumor necrosis factor receptors) triggered by external stimuli, which activate caspase 8 .

The tumor suppressor gene TP53, which encodes p53, is central to DNA damage recognition, DNA repair, cell cycle regulation, proliferation, and apoptosis [96]. Conceivably, multiple p53-related pathways play fundamental roles in the development of cancer, which explains why this gene is most commonly mutated in human malignancies [97]. Substantial evidence has indicated that melatonin regulates proliferation and apoptosis in various cancer types through the p53 signaling pathway, revealing a mechanistic link between melatonin and p53 signaling. Of note, melatonin inhibits cell proliferation by arresting the cell cycle through a p53-mediated rise in the expression of p21WAF1 protein in breast cancer [98].

Melatonin treatment also inhibits the proliferation of hepatocarcinoma cells by promoting cell apoptosis via the upregulation of mitogen-activated protein kinase family members, p38 and c-Jun N-terminal kinase (JNK)-1, -2, and -3 , as well as the elevation of caspase- 8 activity [99]. Additionally, melatonin affects the expression of miR24 microRNA, whose downstream target genes modulate p38 and p53, in colon cancer, breast cancer, and head and neck cancers [100]. A clinical study further revealed that the 1-year survival rate and objective tumor regression rate were significantly higher in cancer patients who were concomitantly treated with melatonin than in those receiving chemotherapy alone [101]. These findings suggest that melatonin contributes to suppression of cell proliferation and induction of apoptosis in head and neck cancer.

\section{Melatonin counteracts metastasis in head and neck cancer}

Cancer metastasis, the spread of cancer cells from the tissues or organs of tumor origin to other sites, is the leading cause of death in cancer patients [39, 102-109]. The cascade of metastasis can be divided into three processes: invasion, intravasation, and extravasation $[39,102,110,111]$. In the process of invasion, the loss of cell-cell adhesion allows malignant tumor cells to escape from primary tumors and to invade the surrounding matrix [112]. This process involves the secretion of enzymes

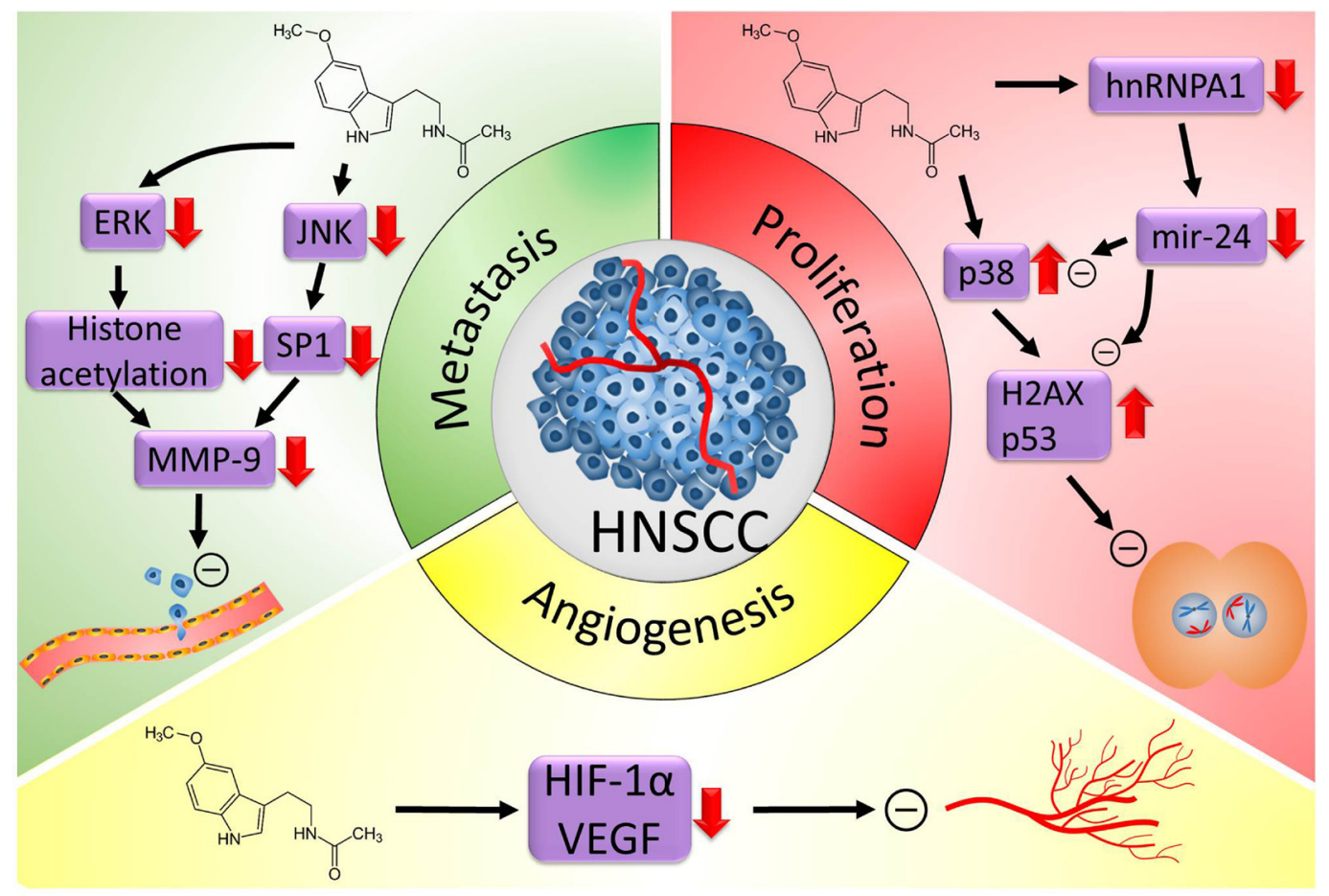

Figure 2: Proposed oncostatic actions of melatonin on head and neck cancer (HNSCC). Melatonin treatment reduces HNSCC cell metastasis through inhibiting the expression of MMP-9 by targeting the ERK/JNK signal pathway to mediate histone acetylation and SP-1 expression. Melatonin inhibits HNSCC cell proliferation through upregulating p38, H2AX and p53 expression and downregulating the expression of hnRNPA1 and mir-24. Melatonin supplementation suppresses NHSCC cells angiogenesis by reducing the expression of angiogenesis molecular markers, HIF-1 $\alpha$ and VEGF. ERK, mitogen-activated protein kinase; JNK, c-Jun N-terminal kinase; MMP-9, matrix metalloproteinase 9; H2AX, H2A histone family member X; hnRNPA1, heterogeneous nuclear ribonucleoprotein A1; HIF-1 $\alpha$, hypoxia inducible factor 1 alpha subunit; VEGF, vascular endothelial growth factor. 


\begin{tabular}{|c|c|c|c|}
\hline Research object & Measures & Outcome & References \\
\hline $\begin{array}{l}250 \text { metastatic solid tumour patients } \\
\text { including } 104 \text { lung cancers, } 77 \text { breast } \\
\text { cancers, } 42 \text { gastrointestinal tract } \\
\text { neoplasms, } 27 \text { head and neck cancers }\end{array}$ & $\begin{array}{l}\text { The percentage of 1-year survival was calculated } \\
\text { in metastatic solid tumour patients that were } \\
\text { randomised to be treated with chemotherapy alone } \\
\text { or chemotherapy plus melatonin }\end{array}$ & $\begin{array}{l}\text { The 1-year survival rate and the objective tumour } \\
\text { regression rate in patients concomitantly treated with } \\
\text { MLT were significantly higher than in those who } \\
\text { received chemotherapy (CT) alone }\end{array}$ & $\begin{array}{l}\text { Lissoni P, et al. } \\
{[101]}\end{array}$ \\
\hline $\begin{array}{l}\text { Oral squamous cell carcinoma cell lines, } \\
\text { SCC- } 9 \text { and SCC- } 25\end{array}$ & $\begin{array}{l}\text { In vitro studies of oral squamous cell carcinoma cell } \\
\text { lines treated with melatonin }\end{array}$ & $\begin{array}{l}\text { Melatonin inhibits expression of molecular markers of } \\
\text { angiogenesis, VEGF and HIF-1 in SCC- } 9 \text { cell line. }\end{array}$ & $\begin{array}{l}\text { Goncalves Ndo N, } \\
\text { et al. [140] }\end{array}$ \\
\hline $\begin{array}{l}\text { Oral squamous cell carcinoma cell lines, } \\
\text { HSC- } 3 \text { and OECM-1 }\end{array}$ & $\begin{array}{l}\text { In vitro studies of oral squamous cell carcinoma cell } \\
\text { lines treated with melatonin }\end{array}$ & $\begin{array}{l}\text { Melatonin affect the motility of HSC- } 3 \text { and OECM-1 } \\
\text { cells in vitro through targeting the ERK pathways to } \\
\text { mediate histone acetylation and then inhibit MMP-9 } \\
\text { transcription }\end{array}$ & $\begin{array}{l}\text { Yeh CM, et al. } \\
{[131]}\end{array}$ \\
\hline $\begin{array}{l}\text { Nasopharyngeal carcinoma cell lines, } \\
\text { HONE- 1, NPC- } 39 \text {, and NPC- BM }\end{array}$ & $\begin{array}{l}\text { In vitro studies of nasopharyngeal carcinoma cell } \\
\text { lines treated with melatonin }\end{array}$ & $\begin{array}{l}\text { Melatonin suppresses the motility of nasopharyngeal } \\
\text { carcinoma cell lines in vitro via inhibiting SP- 1- DNA } \\
\text { binding ability to regulate MMP- } 9 \text { gene expression }\end{array}$ & $\begin{array}{l}\text { Ho HY, et al. } \\
{[132]}\end{array}$ \\
\hline $\begin{array}{l}618 \text { patients with oral cancer and } 560 \text { non- } \\
\text { cancer controls }\end{array}$ & $\begin{array}{l}\text { MTNR1A polymorphism was measured in genomic } \\
\text { DNA samples extracted from blood samples }\end{array}$ & $\begin{array}{l}\text { Oral cancer patients with the } \mathrm{T} / \mathrm{T} \text { allele of MTNR1A } \\
\text { gene variants with betel nut chewing habit have a high } \\
\text { correlation to develop a higher risk for late clinical } \\
\text { staging and lymph node metastasis }\end{array}$ & $\begin{array}{l}\text { Lin FY, et al. } \\
{[163]}\end{array}$ \\
\hline
\end{tabular}

such as matrix metalloproteinases (MMPs) that degrade the extracellular matrix (ECM) and basement membrane [113] and the expression/suppression of proteins involved in controlling cell motility and migration [114]. MMPs, belong to a family of enzymes that contain zinc atoms at their active sites, are secreted by inflammatory phagocytes, connective tissue cells, and many different transformed cells [115]. As a key regulator of ECM remodeling, MMPs function to break down most of the ECM components, including elastin, laminin, collagen, serpin, and fibronectin $[115,116]$. Among MMPs, MMP-2, MMP-9 and membrane-type matrix metalloproteinases (MT-MMPs) are believed to play an important role in cancer invasion and metastasis [109, 117-122]. Mounting evidence has indicated that the inhibition of MMP-2 and MMP-9 activity reduces cancer cell metastasis in head and neck cancer [123-127]. Moreover, in highly metastatic head and neck tumors, MMP-9 is overexpressed compared with that in normal tissues [128-130]. Previous studies also mentioned that melatonin inhibited the gene expression of MMP-9 in head and neck cancers $[131,132]$. The study of melatonin-regulated head and neck cancer metastases has demonstrated that melatonin targeted the ERK/JNK pathways to reduce MMP-9 transcription and cancer cell invasion through modulating histone acetylation and SP1 activation [131].

In addition to ECM remodeling, tumor progression requires the activation of angiogenesis, a process defined as the formation of new blood vessels from pre-existing structures. Blood vessels surrounding the tumor not only supply the oxygen and nutrients [133] but also permit the invasion of cancer cells into the circulatory system and their migration to distal sites $[134,135]$. The process of tumor angiogenesis is orchestrated by multiple signaling pathways elicited by interactions between the tumor cells and the surrounding stroma. Various proteins have been demonstrated to be pro-angiogenic, including but not limited to angiogenin, basic fibroblast growth factor, epidermal growth factor, granulocyte colony-stimulating factor, hepatocyte growth factor, interleukin-8, placental growth factor, platelet-derived endothelial growth factor, transforming growth factor (TGF)- $\alpha$, TGF- $\beta$, tumor necrosis factor- $\alpha$, and vascular endothelial growth factor (VEGF). Among them, the VEGF family and its receptors have drawn considerable attention to the field of tumor angiogenesis [136, 137].

Recently, multiple reports have shown that melatonin can decrease the expression of VEGF in various cancers $[138,139]$. In oral carcinoma and oral cancer cell lines, melatonin inhibited the expression of the proangiogenic factors, HIF $1 \alpha$ and VEGF revealing an effect of melatonin on inhibition of angiogenic responses in oral cancer [140]. These results suggest that melatonin has the potential to inhibit the invasion and metastasis of head and neck cancer by modulating tumor angiogenesis.

\section{Polymorphisms of the melatonin receptor genes MTNR1A and MTNR1B in head and neck cancer}

With the rapid development of the Human Genome Project, the science of pharmacogenetics, which incorporates information on the genetic variability for predicting the response to treatment, is booming. Because the therapeutic index of many chemotherapy drugs for cancer is narrow, a better understanding of pharmacogenetics on cancer chemotherapy may offer individualized cancer treatment [141]. Studies have shown that the variations of individual genomes and tumor genomes affect the drug response in tumors and the risk of developing cancers [142, 143].

Single-nucleotide polymorphism (SNP) occurs as a variation in one nucleotide, which occurs at specific locations in the genome, and each variation has an appreciable degree of detectability in the population [144]. The systematic analysis of candidate gene association has revealed that SNPs in genes involved in cell cycle control ECM remodeling, DNA repair, folate metabolism, and that 
carcinogen metabolism may be associated with increased susceptibility to cancers [145-153].

Mounting evidence indicates that melatonin exhibits oncostatic properties in many cancer types mainly mediated by its membrane-bound receptors, melatonin receptor $1 \mathrm{~A}$ (encoded by $M T N R 1 A)$ and $1 \mathrm{~B}(M T N R 1 B)$. Increased expressions of MTNR $1 A$ and MTNR $1 B$ have been shown to promote the inhibitory actions of melatonin on the growth of cancer cells $[154,155]$. It is documented that the variations of melatonin receptor genes are associated with susceptibility to many diseases [156-160].

The frequencies of the genotypes and allelotypes of SNP rs2119882 for the MTNR1A gene significantly differ between patients with polycystic ovary syndrome and healthy controls [157], while another SNP in the MTNR1A gene, rs7665392, may contribute to breast cancer susceptibility [161]. In addition to $M T N R 1 A$, associations of MTNR1B rs3781638 and rs10765576 with osteoporosis [162] and breast cancer [161], respectively, have been reported. Melatonin receptor gene polymorphisms in combination with environmental parameters have been correlated with the risk for oral cancer [163]. Oral cancer patients who habitually chewed betel nut and carried the T/T allele of MTNR1A rs13140012, were more prone to develop lymph node metastasis and late-stage tumors.

\section{Summary and concluding remarks}

Melatonin is not only a significant immunomodulatory compound but is also a powerful antioxidant that can effectively protect critical molecules from ROS-mediated damage, thereby serving as a vital regulator in cancer suppression. Moreover, melatonin has a very low toxicity profile and is not associated with significant side effects; hence, melatonin has been safely used in various clinical settings [164-166]. In this article, we discussed that melatonin regulates cell proliferation, apoptosis, and metastasis, to exert an anticancer effect. These data provide clues for further clarifying the mechanisms underlying melatonin-mediated inhibition of tumor progression as well as for designing clinical trials for combinational therapies against head and neck cancer.

\section{Abbreviations}

ECM: extracellular matrix; GPCRs: G proteincoupled receptors; JNK: c-Jun N-terminal kinase; MMP: matrix metalloproteinase; MT-MMPs: membranetype matrix metalloproteinases; MTNR1A: melatonin receptor 1A; MTNR1B: melatonin receptor 1B; ROS: reactive oxygen species; SNP: Single-nucleotide polymorphism; TGF: transforming growth factor; VEGF: vascular endothelial growth factor.

\section{CONFLICTS OF INTEREST}

The authors declare no conflicts of interest.

\section{FUNDING}

The authors received no funding for this project.

\section{REFERENCES}

1. Jemal A, Siegel R, Ward E, Hao Y, Xu J, Thun MJ. Cancer statistics, 2009. CA Cancer J Clin. 2009; 59:225-249.

2. Boyle P, Levin B. World Cancer Report 2008. Lyon: IARC Press, International Agency for Research on Cancer, 2008.

3. Hashibe M, Brennan P, Chuang SC, Boccia S, Castellsague X, Chen C, Curado MP, Dal Maso L, Daudt AW, Fabianova E, Fernandez L, Wunsch-Filho V, Franceschi S, et al. Interaction between tobacco and alcohol use and the risk of head and neck cancer: pooled analysis in the International Head and Neck Cancer Epidemiology Consortium. Cancer Epidemiol Biomarkers Prev. 2009; 18:541-550.

4. Su SC, Lin CW, Liu YF, Fan WL, Chen MK, Yu CP, Yang WE, Su CW, Chuang CY, Li WH, Chung WH, Yang SF. Exome Sequencing of Oral Squamous Cell Carcinoma Reveals Molecular Subgroups and Novel Therapeutic Opportunities. Theranostics. 2017; 7:1088-1099.

5. Chowdhury N, Alvi S, Kimura K, Tawfik O, Manna P, Beahm D, Robinson A, Kerley S, Hoover L. Outcomes of HPVrelated nasal squamous cell carcinoma. Laryngoscope. 2017.

6. Shaikh MH, McMillan NA, Johnson NW. HPV-associated head and neck cancers in the Asia Pacific: A critical literature review \& meta-analysis. Cancer Epidemiol. 2015; 39:923-938.

7. Lerner AB, Case JD, Takahashi Y, Lee TH, Mori W. Isolation of melatonin, the pineal gland factor that lightens melanocyteS1. Journal of the American Chemical Society. $1958 ; 80: 2587-2587$.

8. Hardeland R, Poeggeler B. Non-vertebrate melatonin. J Pineal Res. 2003; 34:233-241.

9. Agorastos A, Linthorst AC. Potential pleiotropic beneficial effects of adjuvant melatonergic treatment in posttraumatic stress disorder. J Pineal Res. 2016; 61:3-26.

10. Back K, Tan DX, Reiter RJ. Melatonin biosynthesis in plants: multiple pathways catalyze tryptophan to melatonin in the cytoplasm or chloroplasts. J Pineal Res. 2016; 61:426-437.

11. Manchester LC, Coto-Montes A, Boga JA, Andersen LP, Zhou Z, Galano A, Vriend J, Tan DX, Reiter RJ. Melatonin: an ancient molecule that makes oxygen metabolically tolerable. J Pineal Res. 2015; 59:403-419.

12. Arnao MB, Hernandez-Ruiz J. Functions of melatonin in plants: a review. J Pineal Res. 2015; 59:133-150.

13. Stehle JH, Saade A, Rawashdeh O, Ackermann K, Jilg A, Sebesteny T, Maronde E. A survey of molecular details in the human pineal gland in the light of phylogeny, structure, function and chronobiological diseases. J Pineal Res. 2011; 51:17-43.

14. Tast A, Love RJ, Evans G, Telsfer S, Giles R, Nicholls P, Voultsios A, Kennaway DJ. The pattern of melatonin 
secretion is rhythmic in the domestic pig and responds rapidly to changes in daylength. J Pineal Res. 2001; 31:294-300.

15. Tan DX, Hardeland R, Back K, Manchester LC, AlatorreJimenez MA, Reiter RJ. On the significance of an alternate pathway of melatonin synthesis via 5-methoxytryptamine: comparisons across species. J Pineal Res. 2016; 61:27-40.

16. Legros C, Chesneau D, Boutin JA, Barc C, Malpaux B. Melatonin from cerebrospinal fluid but not from blood reaches sheep cerebral tissues under physiological conditions. J Neuroendocrinol. 2014; 26:151-163.

17. Reiter RJ, Tan DX, Kim SJ, Cruz MH. Delivery of pineal melatonin to the brain and SCN: role of canaliculi, cerebrospinal fluid, tanycytes and Virchow-Robin perivascular spaces. Brain Struct Funct. 2014; 219:1873-1887.

18. Dawson D, Encel N. Melatonin and sleep in humans. J Pineal Res. 1993; 15:1-12.

19. Reiter RJ, Tan DX, Korkmaz A. The circadian melatonin rhythm and its modulation: possible impact on hypertension. J Hypertens Suppl. 2009; 27:S17-20.

20. Calvo JR, Gonzalez-Yanes C, Maldonado MD. The role of melatonin in the cells of the innate immunity: a review. J Pineal Res. 2013; 55:103-120.

21. Reiter RJ, Tan DX, Galano A. Melatonin: exceeding expectations. Physiology (Bethesda). 2014; 29:325-333.

22. Pechanova O, Paulis L, Simko F. Peripheral and central effects of melatonin on blood pressure regulation. Int J Mol Sci. 2014; 15:17920-17937.

23. Slominski RM, Reiter RJ, Schlabritz-Loutsevitch N, Ostrom RS, Slominski AT. Melatonin membrane receptors in peripheral tissues: distribution and functions. Mol Cell Endocrinol. 2012; 351:152-166.

24. Dubocovich ML, Markowska M. Functional MT1 and MT2 melatonin receptors in mammals. Endocrine. 2005; 27:101-110.

25. Dubocovich ML, Delagrange P, Krause DN, Sugden D, Cardinali DP, Olcese J. International Union of Basic and Clinical Pharmacology. LXXV. Nomenclature, classification, and pharmacology of $\mathrm{G}$ protein-coupled melatonin receptors. Pharmacol Rev. 2010; 62:343-380.

26. Dubocovich ML, Rivera-Bermudez MA, Gerdin MJ, Masana MI. Molecular pharmacology, regulation and function of mammalian melatonin receptors. Front Biosci. 2003; 8:d1093-1108.

27. Masana MI, Dubocovich ML. Melatonin receptor signaling: finding the path through the dark. Sci STKE. 2001; 2001: pe39.

28. Slaugenhaupt SA, Roca AL, Liebert CB, Altherr MR, Gusella JF, Reppert SM. Mapping of the gene for the Mella-melatonin receptor to human chromosome 4 (MTNR1A) and mouse chromosome 8 (Mtnr1a). Genomics. 1995; 27:355-357.

29. Reppert SM, Weaver DR, Godson C. Melatonin receptors step into the light: cloning and classification of subtypes. Trends Pharmacol Sci. 1996; 17:100-102.
30. Ferguson SS. Evolving concepts in G protein-coupled receptor endocytosis: the role in receptor desensitization and signaling. Pharmacol Rev. 2001; 53:1-24.

31. Wang RX, Liu H, Xu L, Zhang H, Zhou RX. Involvement of nuclear receptor RZR/RORgamma in melatonin-induced HIF-1alpha inactivation in SGC-7901 human gastric cancer cells. Oncol Rep. 2015; 34:2541-2546.

32. Shajari S, Laliena A, Heegsma J, Tunon MJ, Moshage H, Faber KN. Melatonin suppresses activation of hepatic stellate cells through RORalpha-mediated inhibition of 5-lipoxygenase. J Pineal Res. 2015; 59:391-401.

33. Pozo D, Reiter RJ, Calvo JR, Guerrero JM. Inhibition of cerebellar nitric oxide synthase and cyclic GMP production by melatonin via complex formation with calmodulin. J Cell Biochem. 1997; 65:430-442.

34. Boutin JA. Quinone reductase 2 as a promising target of melatonin therapeutic actions. Expert Opin Ther Targets. 2016; 20:303-317.

35. Peschke E, Bahr I, Muhlbauer E. Experimental and clinical aspects of melatonin and clock genes in diabetes. J Pineal Res. 2015; 59:1-23.

36. Hill SM, Belancio VP, Dauchy RT, Xiang S, Brimer S, Mao L, Hauch A, Lundberg PW, Summers W, Yuan L, Frasch T, Blask DE. Melatonin: an inhibitor of breast cancer. Endocr Relat Cancer. 2015; 22:R183-204.

37. Carrillo-Vico A, Guerrero JM, Lardone PJ, Reiter RJ. A review of the multiple actions of melatonin on the immune system. Endocrine. 2005; 27:189-200.

38. Hosseinzadeh A, Kamrava SK, Joghataei MT, Darabi R, Shakeri-Zadeh A, Shahriari M, Reiter RJ, Ghaznavi H, Mehrzadi S. Apoptosis signaling pathways in osteoarthritis and possible protective role of melatonin. J Pineal Res. 2016; 61:411-425.

39. Reiter RJ, Rosales-Corral SA, Tan DX, AcunaCastroviejo D, Qin L, Yang SF, Xu K. Melatonin, a Full Service Anti-Cancer Agent: Inhibition of Initiation, Progression and Metastasis. Int J Mol Sci. 2017; 18:E841.

40. Chuffa LGA, Reiter RJ, Lupi Junior LA. Melatonin as a Promising Agent to Treat Ovarian Cancer:Molecular Mechanisms. Carcinogenesis. 2017.

41. Li Y, Li S, Zhou Y, Meng X, Zhang JJ, Xu DP, Li HB. Melatonin for the prevention and treatment of cancer. Oncotarget. 2017; 8:39896-39921. https://doi.org/10.18632/ oncotarget.16379.

42. Mao L, Dauchy RT, Blask DE, Dauchy EM, Slakey LM, Brimer S, Yuan L, Xiang S, Hauch A, Smith K, Frasch T, Belancio VP, Wren MA, et al. Melatonin suppression of aerobic glycolysis (Warburg effect), survival signalling and metastasis in human leiomyosarcoma. J Pineal Res. 2016; 60:167-177.

43. Crooke A, Huete-Toral F, Colligris B, Pintor J. The role and therapeutic potential of melatonin in age-related ocular diseases. J Pineal Res. 2017. 
44. Han L, Wang H, Li L, Li X, Ge J, Reiter RJ, Wang Q. Melatonin protects against maternal obesity-associated oxidative stress and meiotic defects in oocytes via the SIRT3-SOD2 dependent pathway. J Pineal Res 2017.

45. Liu Z, Gan L, Xu Y, Luo D, Ren Q, Wu S, Sun C. Melatonin alleviates inflammasome-induced pyroptosis through inhibiting NF-kappaB/GSDMD signal in mice adipose tissue. J Pineal Res. 2017; 63.

46. Majidinia M, Sadeghpour A, Mehrzadi S, Reiter RJ, Khatami N, Yousefi B. Melatonin: A pleiotropic molecule that modulates DNA damage response and repair pathways. J Pineal Res. 2017; 63.

47. Zhai M, Li B, Duan W, Jing L, Zhang B, Zhang M, Yu L, Liu Z, Yu B, Ren K, Gao E, Yang Y, Liang H, et al. Melatonin ameliorates myocardial ischemia reperfusion injury through SIRT3-dependent regulation of oxidative stress and apoptosis. J Pineal Res. 2017.

48. Tan DX CL, Poeggler B, Manchester LC, Reiter RJ. Melatonin: a potent, endogenous hydroxyl radical scavenger. Endocrine. 1993; 1:57-60.

49. Reiter RJ, Mayo JC, Tan DX, Sainz RM, AlatorreJimenez M, Qin L. Melatonin as an antioxidant: under promises but over delivers. J Pineal Res. 2016; 61:253-278.

50. Aranda ML, Gonzalez Fleitas MF, De Laurentiis A, Keller Sarmiento MI, Chianelli M, Sande PH, Dorfman D, Rosenstein RE. Neuroprotective effect of melatonin in experimental optic neuritis in rats. J Pineal Res. 2016; 60:360-372.

51. Nduhirabandi F, Lamont K, Albertyn Z, Opie LH, Lecour S. Role of toll-like receptor 4 in melatonin-induced cardioprotection. J Pineal Res. 2016; 60:39-47.

52. Reiter RJ. Oxidative damage in the central nervous system: protection by melatonin. Prog Neurobiol. 1998; 56:359-384.

53. Korkmaz A, Reiter RJ, Topal T, Manchester LC, Oter S, Tan DX. Melatonin: an established antioxidant worthy of use in clinical trials. Mol Med. 2009; 15:43-50.

54. Lowes DA, Almawash AM, Webster NR, Reid VL, Galley HF. Melatonin and structurally similar compounds have differing effects on inflammation and mitochondrial function in endothelial cells under conditions mimicking sepsis. Br J Anaesth. 2011; 107:193-201.

55. Acuna-Castroviejo D, Escames G, Venegas C, DiazCasado ME, Lima-Cabello E, Lopez LC, Rosales-Corral S, Tan DX, Reiter RJ. Extrapineal melatonin: sources, regulation, and potential functions. Cell Mol Life Sci. 2014; 71:2997-3025.

56. Tan DX, Manchester LC, Terron MP, Flores LJ, Reiter RJ. One molecule, many derivatives: a never-ending interaction of melatonin with reactive oxygen and nitrogen species? J Pineal Res. 2007; 42:28-42.

57. Tan DX, Manchester LC, Terron MP, Flores LJ, Tamura H, Reiter RJ. Melatonin as a naturally occurring co-substrate of quinone reductase-2, the putative MT3 melatonin membrane receptor: hypothesis and significance. J Pineal Res. 2007; 43:317-320.
58. Barlow-Walden LR, Reiter RJ, Abe M, Pablos M, Menendez-Pelaez A, Chen LD, Poeggeler B. Melatonin stimulates brain glutathione peroxidase activity. Neurochem Int. 1995; 26:497-502.

59. Pablos MI, Reiter RJ, Ortiz GG, Guerrero JM, Agapito MT, Chuang JI, Sewerynek E. Rhythms of glutathione peroxidase and glutathione reductase in brain of chick and their inhibition by light. Neurochem Int. 1998; 32:69-75.

60. Reiter RJ, Tan DX, Osuna C, Gitto E. Actions of melatonin in the reduction of oxidative stress. A review. J Biomed Sci. 2000; 7:444-458.

61. Rodriguez C, Mayo JC, Sainz RM, Antolin I, Herrera F, Martin V, Reiter RJ. Regulation of antioxidant enzymes: a significant role for melatonin. J Pineal Res. 2004; 36:1-9.

62. Devasagayam TP, Tilak JC, Boloor KK, Sane KS, Ghaskadbi SS, Lele RD. Free radicals and antioxidants in human health: current status and future prospects. J Assoc Physicians India. 2004; 52:794-804.

63. Zhang HM, Zhang Y. Melatonin: a well-documented antioxidant with conditional pro-oxidant actions. J Pineal Res. 2014; 57:131-146.

64. Bizzarri M, Proietti S, Cucina A, Reiter RJ. Molecular mechanisms of the pro-apoptotic actions of melatonin in cancer: a review. Expert Opin Ther Targets. 2013; 17:1483-1496.

65. Wolfler A, Caluba HC, Abuja PM, Dohr G, Schauenstein K, Liebmann PM. Prooxidant activity of melatonin promotes fas-induced cell death in human leukemic Jurkat cells. FEBS Lett. 2001; 502:127-131.

66. Osseni RA, Rat P, Bogdan A, Warnet JM, Touitou Y. Evidence of prooxidant and antioxidant action of melatonin on human liver cell line HepG2. Life Sci. 2000; 68:387-399.

67. Pariente R, Pariente JA, Rodriguez AB, Espino J. Melatonin sensitizes human cervical cancer HeLa cells to cisplatininduced cytotoxicity and apoptosis: effects on oxidative stress and DNA fragmentation. J Pineal Res. 2016; 60:55-64.

68. Um HJ, Kwon TK. Protective effect of melatonin on oxaliplatin-induced apoptosis through sustained Mcl-1 expression and anti-oxidant action in renal carcinoma Caki cells. J Pineal Res. 2010; 49:283-290.

69. Buelna-Chontal M, Zazueta C. Redox activation of Nrf2 \& NF-kappaB: a double end sword? Cell Signal. 2013; 25:2548-2557.

70. du Plessis SS, Hagenaar K, Lampiao F. The in vitro effects of melatonin on human sperm function and its scavenging activities on NO, ROS. Andrologia. 2010; 42:112-116.

71. Zavodnik IB, Domanski AV, Lapshina EA, Bryszewska M, Reiter RJ. Melatonin directly scavenges free radicals generated in red blood cells and a cell-free system: chemiluminescence measurements and theoretical calculations. Life Sci. 2006; 79:391-400.

72. Poeggeler B, Reiter RJ, Hardeland R, Tan DX, BarlowWalden LR. Melatonin and structurally-related, endogenous indoles act as potent electron donors and radical scavengers in vitro. Redox Rep. 1996; 2:179-184. 
73. Broncel M, Kozirog-Kolacinska M, Chojnowska-Jezierska J. Melatonin in the treatment of atherosclerosis. [Article in Polish]. Pol Merkur Lekarski. 2007; 23:124-127.

74. Skaper SD, Floreani M, Ceccon M, Facci L, Giusti P. Excitotoxicity, oxidative stress, and the neuroprotective potential of melatonin. Ann N Y Acad Sci. 1999; 890:107-118.

75. Ravindra T, Lakshmi NK, Ahuja YR. Melatonin in pathogenesis and therapy of cancer. Indian J Med Sci. 2006; 60:523-535.

76. Di Bella G, Mascia F, Gualano L, Di Bella L. Melatonin anticancer effects: review. Int J Mol Sci. 2013; 14:2410-2430.

77. Lissoni P, Chilelli M, Villa S, Cerizza L, Tancini G. Five years survival in metastatic non-small cell lung cancer patients treated with chemotherapy alone or chemotherapy and melatonin: a randomized trial. J Pineal Res. 2003; $35: 12-15$.

78. Lissoni P, Bucovec R, Bonfanti A, Giani L, Mandelli A, Roselli MG, Rovelli F, Fumagalli L. Thrombopoietic properties of 5-methoxytryptamine plus melatonin versus melatonin alone in the treatment of cancer-related thrombocytopenia. J Pineal Res. 2001; 30:123-126.

79. Lissoni P. Biochemotherapy with immunomodulating pineal hormones other than melatonin: 5-methoxytryptamine as a new oncostatic pineal agent. Pathol Biol (Paris). 2007; 55:198-200.

80. Dauchy RT, Blask DE, Dauchy EM, Davidson LK, Tirrell PC, Greene MW, Tirrell RP, Hill CR, Sauer LA. Antineoplastic effects of melatonin on a rare malignancy of mesenchymal origin: melatonin receptor-mediated inhibition of signal transduction, linoleic acid metabolism and growth in tissue-isolated human leiomyosarcoma xenografts. J Pineal Res. 2009; 47:32-42.

81. Cutando A, Gomez-Moreno G, Arana C, AcunaCastroviejo D, Reiter RJ. Melatonin: potential functions in the oral cavity. J Periodontol. 2007; 78:1094-1102.

82. Reiter RJ, Rosales-Corral SA, Liu XY, AcunaCastroviejo D, Escames G, Tan DX. Melatonin in the oral cavity: physiological and pathological implications. J Periodontal Res. 2015; 50:9-17.

83. Ortiz F, Acuna-Castroviejo D, Doerrier C, Dayoub JC, Lopez LC, Venegas C, Garcia JA, Lopez A, Volt H, LunaSanchez M, Escames G. Melatonin blunts the mitochondrial/ NLRP3 connection and protects against radiation-induced oral mucositis. J Pineal Res. 2015; 58:34-49.

84. Seidman MD, Quirk WS, Shirwany NA. Reactive oxygen metabolites, antioxidants and head and neck cancer. Head Neck. 1999; 21:467-479.

85. Stratton MR, Campbell PJ, Futreal PA. The cancer genome. Nature. 2009; 458:719-724.

86. Hanahan D, Weinberg RA. Hallmarks of cancer: the next generation. Cell. 2011; 144:646-674.

87. Mayo JC, Sainz RM, Gonzalez Menendez P, Cepas V, Tan DX, Reiter RJ. Melatonin and sirtuins: A "not-so unexpected" relationship. J Pineal Res. 2017; 62.
88. Fernandez A, Ordonez R, Reiter RJ, Gonzalez-Gallego J, Mauriz JL. Melatonin and endoplasmic reticulum stress: relation to autophagy and apoptosis. J Pineal Res. 2015; 59:292-307.

89. Evan GI, Vousden KH. Proliferation, cell cycle and apoptosis in cancer. Nature. 2001; 411:342-348.

90. Sherr CJ, Weber JD. The ARF/p53 pathway. Curr Opin Genet Dev. 2000; 10:94-99.

91. Hollstein M, Sidransky D, Vogelstein B, Harris CC. p53 mutations in human cancers. Science. 1991; 253:49-53.

92. Norbury CJ, Hickson ID. Cellular responses to DNA damage. Annu Rev Pharmacol Toxicol. 2001; 41:367-401.

93. Gupta SC, Francis SK, Nair MS, Mo YY, Aggarwal BB. Azadirone, a limonoid tetranortriterpene, induces death receptors and sensitizes human cancer cells to tumor necrosis factor-related apoptosis-inducing ligand (TRAIL) through a p53 protein-independent mechanism: evidence for the role of the ROS-ERK-CHOP-death receptor pathway. J Biol Chem. 2013; 288:32343-32356.

94. Song H, Wei M, Liu W, Shen S, Li J, Wang L. Cisplatin induced apoptosis of ovarian cancer A2780s cells by activation of ERK/p53/PUMA signals. Histol Histopathol. $2017 ; 11889$.

95. Elmore S. Apoptosis: a review of programmed cell death. Toxicol Pathol. 2007; 35:495-516.

96. Robles AI, Harris CC. p53-mediated apoptosis and genomic instability diseases. Acta Oncol. 2001; 40:696-701.

97. Sigal A, Rotter V. Oncogenic mutations of the p53 tumor suppressor: the demons of the guardian of the genome. Cancer Res. 2000; 60:6788-6793.

98. Mediavilla MD, Cos S, Sanchez-Barcelo EJ. Melatonin increases p53 and p21WAF1 expression in MCF-7 human breast cancer cells in vitro. Life Sci. 1999; 65:415-420.

99. Martin-Renedo J, Mauriz JL, Jorquera F, Ruiz-Andres O, Gonzalez P, Gonzalez-Gallego J. Melatonin induces cell cycle arrest and apoptosis in hepatocarcinoma HepG2 cell line. J Pineal Res. 2008; 45:532-540.

100. Mori F, Ferraiuolo M, Santoro R, Sacconi A, Goeman F, Pallocca M, Pulito C, Korita E, Fanciulli M, Muti P, Blandino G, Strano S. Multitargeting activity of miR-24 inhibits long-term melatonin anticancer effects. Oncotarget. 2016; 7:20532-20548. https://doi.org/10.18632/ oncotarget.7978.

101. Lissoni P, Barni S, Mandala M, Ardizzoia A, Paolorossi F, Vaghi M, Longarini R, Malugani F, Tancini G. Decreased toxicity and increased efficacy of cancer chemotherapy using the pineal hormone melatonin in metastatic solid tumour patients with poor clinical status. Eur J Cancer. 1999; 35:1688-1692.

102. Su SC, Hsieh MJ, Yang WE, Chung WH, Reiter RJ, Yang SF. Cancer metastasis: Mechanisms of inhibition by melatonin. J Pineal Res. 2017; 62.

103. Cheng HL, Hsieh MJ, Yang JS, Lin CW, Lue KH, Lu KH, Yang SF. Nobiletin inhibits human osteosarcoma cells 
metastasis by blocking ERK and JNK-mediated MMPs expression. Oncotarget. 2016; 7:35208-35223. https://doi. org/10.18632/oncotarget.9106.

104. Cheng HL, Lin CW, Yang JS, Hsieh MJ, Yang SF, Lu KH. Zoledronate blocks geranylgeranylation not farnesylation to suppress human osteosarcoma U2OS cells metastasis by EMT via Rho A activation and FAK-inhibited JNK and p38 pathways. Oncotarget. 2016; 7:9742-9758. https://doi. org/10.18632/oncotarget.7138.

105. Hsin CH, Chou YE, Yang SF, Su SC, Chuang YT, Lin SH, Lin CW. MMP-11 promoted the oral cancer migration and Fak/Src activation. Oncotarget. 2017; 8:32783-32793. https://doi.org/10.18632/oncotarget.15824.

106. Lin CW, Yang WE, Lee WJ, Hua KT, Hsieh FK, Hsiao M, Chen CC, Chow JM, Chen MK, Yang SF, Chien MH. Lipocalin 2 prevents oral cancer metastasis through carbonic anhydrase IX inhibition and is associated with favourable prognosis. Carcinogenesis. 2016; 37:712-722.

107. Su SC, Lin CW, Yang WE, Fan WL, Yang SF. The urokinase-type plasminogen activator (uPA) system as a biomarker and therapeutic target in human malignancies. Expert Opin Ther Targets. 2016; 20:551-566.

108. Yang JS, Lin CW, Chuang CY, Su SC, Lin SH, Yang SF. Carbonic anhydrase IX overexpression regulates the migration and progression in oral squamous cell carcinoma. Tumour Biol. 2015; 36:9517-9524.

109. Yang JS, Lin CW, Su SC, Yang SF. Pharmacodynamic considerations in the use of matrix metalloproteinase inhibitors in cancer treatment. Expert Opin Drug Metab Toxicol. 2016; 12:191-200.

110. Lin YW, Lee LM, Lee WJ, Chu CY, Tan P, Yang YC, Chen WY, Yang SF, Hsiao M, Chien MH. Melatonin inhibits MMP-9 transactivation and renal cell carcinoma metastasis by suppressing Akt-MAPKs pathway and NF-kappaB DNA-binding activity. J Pineal Res. 2016; 60:277-290.

111. Borin TF, Arbab AS, Gelaleti GB, Ferreira LC, Moschetta MG, Jardim-Perassi BV, Iskander AS, Varma NR, Shankar A, Coimbra VB, Fabri VA, de Oliveira JG, Zuccari DA. Melatonin decreases breast cancer metastasis by modulating Rho-associated kinase protein-1 expression. J Pineal Res. 2016; 60:3-15.

112. Bendas G, Borsig L. Cancer cell adhesion and metastasis: selectins, integrins, and the inhibitory potential of heparins. Int J Cell Biol. 2012; 2012:676731.

113. Duffy MJ. The role of proteolytic enzymes in cancer invasion and metastasis. Clin Exp Metastasis. 1992; 10:145-155.

114. Larue L, Bellacosa A. Epithelial-mesenchymal transition in development and cancer: role of phosphatidylinositol 3' kinase/AKT pathways. Oncogene. 2005; 24:7443-7454.

115. Woessner JF Jr. Matrix metalloproteinases and their inhibitors in connective tissue remodeling. Faseb j. 1991; 5:2145-2154.

116. Matrisian LM, Hogan BL. Growth factor-regulated proteases and extracellular matrix remodeling during mammalian development. Curr Top Dev Biol. 1990; 24:219-259.
117. Sato H, Seiki M. Membrane-type matrix metalloproteinases (MT-MMPs) in tumor metastasis. J Biochem. 1996; 119:209-215.

118. Chang PY, Hsieh MJ, Hsieh YS, Chen PN, Yang JS, Lo FC, Yang SF, Lu KH. Tricetin inhibits human osteosarcoma cells metastasis by transcriptionally repressing MMP-9 via p38 and Akt pathways. Environ Toxicol. 2017; 32:2032-2040.

119. Chien MH, Lin CW, Cheng CW, Wen YC, Yang SF. Matrix metalloproteinase-2 as a target for head and neck cancer therapy. Expert Opin Ther Targets. 2013; 17:203-216.

120. Kao SJ, Su JL, Chen CK, Yu MC, Bai KJ, Chang JH, Bien MY, Yang SF, Chien MH. Osthole inhibits the invasive ability of human lung adenocarcinoma cells via suppression of NF-kappaB-mediated matrix metalloproteinase-9 expression. Toxicol Appl Pharmacol. 2012; 261:105-115.

121. Lin CW, Chen PN, Chen MK, Yang WE, Tang CH, Yang SF, Hsieh YS. Kaempferol reduces matrix metalloproteinase-2 expression by down-regulating ERK1/2 and the activator protein-1 signaling pathways in oral cancer cells. PLoS One. 2013; 8:e80883.

122. Yang SF, Lee WJ, Tan P, Tang CH, Hsiao M, Hsieh FK, Chien MH. Upregulation of miR-328 and inhibition of CREB-DNA-binding activity are critical for resveratrolmediated suppression of matrix metalloproteinase- 2 and subsequent metastatic ability in human osteosarcomas. Oncotarget. 2015; 6:2736-2753. https://doi.org/10.18632/ oncotarget. 3088.

123. Chung HH, Chen MK, Chang YC, Yang SF, Lin CC, Lin CW. Inhibitory effects of Leucaena leucocephala on the metastasis and invasion of human oral cancer cells. Environ Toxicol. 2017; 32:1765-1774.

124. Hsieh MJ, Chen JC, Yang WE, Chien SY, Chen MK, Lo YS, Hsi YT, Chuang YC, Lin CC, Yang SF. Dehydroandrographolide inhibits oral cancer cell migration and invasion through NF-kappaB-, AP-1-, and SP-1modulated matrix metalloproteinase-2 inhibition. Biochem Pharmacol. 2017; 130:10-20.

125. Huang YW, Chuang CY, Hsieh YS, Chen PN, Yang SF, Shih Hsuan L, Chen YY, Lin CW, Chang YC. Rubus idaeus extract suppresses migration and invasion of human oral cancer by inhibiting MMP-2 through modulation of the Erk1/2 signaling pathway. Environ Toxicol. 2017; 32:1037-1046.

126. Lin CW, Chou YE, Chiou HL, Chen MK, Yang WE, Hsieh MJ, Yang SF. Pterostilbene suppresses oral cancer cell invasion by inhibiting MMP-2 expression. Expert Opin Ther Targets. 2014; 18:1109-1120.

127. Lin FY, Hsieh YH, Yang SF, Chen CT, Tang CH, Chou MY, Chuang YT, Lin CW, Chen MK. Resveratrol suppresses TPA-induced matrix metalloproteinase-9 expression through the inhibition of MAPK pathways in oral cancer cells. J Oral Pathol Med. 2015; 44:699-706.

128. Burduk PK, Bodnar M, Sawicki P, Szylberg L, Wisniewska E, Kazmierczak W, Martynska M, Marszalek A. Expression of metalloproteinases 2 and 9 and tissue inhibitors 1 and 2 
as predictors of lymph node metastases in oropharyngeal squamous cell carcinoma. Head Neck. 2015; 37:418-422.

129. Patel BP, Shah PM, Rawal UM, Desai AA, Shah SV, Rawal RM, Patel PS. Activation of MMP-2 and MMP-9 in patients with oral squamous cell carcinoma. J Surg Oncol. 2005; 90:81-88.

130. Patel BP, Shah SV, Shukla SN, Shah PM, Patel PS. Clinical significance of MMP-2 and MMP-9 in patients with oral cancer. Head Neck. 2007; 29:564-572.

131. Yeh CM, Lin CW, Yang JS, Yang WE, Su SC, Yang SF. Melatonin inhibits TPA-induced oral cancer cell migration by suppressing matrix metalloproteinase- 9 activation through the histone acetylation. Oncotarget. 2016; 7:21952-21967. https://doi.org/10.18632/oncotarget.8009.

132. Ho HY, Lin CW, Chien MH, Reiter RJ, Su SC, Hsieh YH, Yang SF. Melatonin suppresses TPA-induced metastasis by downregulating matrix metalloproteinase-9 expression through JNK/SP-1 signaling in nasopharyngeal carcinoma. J Pineal Res. 2016; 61:479-492.

133. Folkman J. Tumor angiogenesis: therapeutic implications. N Engl J Med. 1971; 285:1182-1186.

134. Carmeliet P, Jain RK. Angiogenesis in cancer and other diseases. Nature. 2000; 407:249-257.

135. Nishida N, Yano H, Nishida T, Kamura T, Kojiro M. Angiogenesis in Cancer. Vasc Health Risk Manag. 2006; 2:213-219.

136. de Fraipont F, El Atifi M, Gicquel C, Bertagna X, Chambaz EM, Feige JJ. Expression of the angiogenesis markers vascular endothelial growth factor-A, thrombospondin-1, and plateletderived endothelial cell growth factor in human sporadic adrenocortical tumors: correlation with genotypic alterations. J Clin Endocrinol Metab. 2000; 85:4734-4741.

137. Shih SC, Robinson GS, Perruzzi CA, Calvo A, Desai K, Green JE, Ali IU, Smith LEH, Senger DR. Molecular Profiling of Angiogenesis Markers. Am J Pathol. 2002; 161:35-41.

138. Carbajo-Pescador S, Ordonez R, Benet M, Jover R, GarciaPalomo A, Mauriz JL, Gonzalez-Gallego J. Inhibition of VEGF expression through blockade of Hiflalpha and STAT3 signalling mediates the anti-angiogenic effect of melatonin in HepG2 liver cancer cells. Br J Cancer. 2013; 109:83-91.

139. Colombo J, Maciel JMW, Ferreira LC, Da Silva RF, Zuccari DAP. Effects of melatonin on HIF- $1 \alpha$ and VEGF expression and on the invasive properties of hepatocarcinoma cells. Oncol Lett. 2016; 12:231-237.

140. Goncalves Ndo N, Rodrigues RV, Jardim-Perassi BV, Moschetta MG, Lopes JR, Colombo J, Zuccari DA. Molecular markers of angiogenesis and metastasis in lines of oral carcinoma after treatment with melatonin. Anticancer Agents Med Chem. 2014; 14:1302-1311.

141. Relling MV, Dervieux T. Pharmacogenetics and cancer therapy. Nat Rev Cancer. 2001; 1:99-108.

142. Andersson KE, Arner A. Urinary bladder contraction and relaxation: physiology and pathophysiology. Physiol Rev. 2004; 84:935-986.
143. Coyne KS, Payne C, Bhattacharyya SK, Revicki DA, Thompson C, Corey R, Hunt TL. The impact of urinary urgency and frequency on health-related quality of life in overactive bladder: results from a national community survey. Value Health. 2004; 7:455-463.

144. Syvanen AC. Accessing genetic variation: genotyping single nucleotide polymorphisms. Nat Rev Genet. 2001; 2:930-942.

145. Cheng HL, Liu YF, Su CW, Su SC, Chen MK, Yang SF, Lin CW. Functional genetic variant in the Kozak sequence of WW domain-containing oxidoreductase (WWOX) gene is associated with oral cancer risk. Oncotarget. 2016; 7:69384-69396. https://doi.org/10.18632/oncotarget.12082.

146. Chou CH, Chou YE, Chuang CY, Yang SF, Lin CW. Combined effect of genetic polymorphisms of AURKA and environmental factors on oral cancer development in Taiwan. PLoS One. 2017; 12:e0171583.

147. Chou YE, Hsieh MJ, Hsin CH, Chiang WL, Lai YC, Lee YH, Huang SC, Yang SF, Lin CW. CD44 gene polymorphisms and environmental factors on oral cancer susceptibility in Taiwan. PLoS One. 2014; 9:e93692.

148. Hua KT, Liu YF, Hsu CL, Cheng TY, Yang CY, Chang JS, Lee WJ, Hsiao M, Juan HF, Chien MH, Yang SF. 3'UTR polymorphisms of carbonic anhydrase IX determine the miR-34a targeting efficiency and prognosis of hepatocellular carcinoma. Sci Rep. 2017; 7:4466.

149. Lin CW, Chou YE, Yeh CM, Yang SF, Chuang CY, Liu YF. A functional variant at the miRNA binding site in HMGB1 gene is associated with risk of oral squamous cell carcinoma. Oncotarget. 2017; 8:34630-34642. https://doi. org/10.18632/oncotarget.16120.

150. Lin CW, Yang SF, Chuang CY, Lin HP, Hsin CH. Association of matrix metalloproteinase-11 polymorphisms with susceptibility and clinicopathologic characteristics for oral squamous cell carcinoma. Head Neck. 2015; 37:1425-1431.

151. Su CW, Huang YW, Chen MK, Su SC, Yang SF, Lin CW. Polymorphisms and Plasma Levels of Tissue Inhibitor of Metalloproteinase-3: Impact on Genetic Susceptibility and Clinical Outcome of Oral Cancer. Medicine (Baltimore). 2015; 94:e2092.

152. Su KJ, Ho CC, Lin CW, Chen MK, Su SC, Yu YL, Yang SF. Combinations of FUT2 gene polymorphisms and environmental factors are associated with oral cancer risk. Tumour Biol. 2016; 37:6647-6652.

153. Su SC, Hsieh MJ, Liu YF, Chou YE, Lin CW, Yang SF. ADAMTS14 Gene Polymorphism and Environmental Risk in the Development of Oral Cancer. PLoS One. 2016; 11:e0159585.

154. Collins A, Yuan L, Kiefer TL, Cheng Q, Lai L, Hill SM. Overexpression of the MT1 melatonin receptor in $\mathrm{MCF}-7$ human breast cancer cells inhibits mammary tumor formation in nude mice. Cancer Lett. 2003; 189:49-57.

155. Lai L, Yuan L, Cheng Q, Dong C, Mao L, Hill SM. Alteration of the MT1 melatonin receptor gene and its expression in primary human breast tumors and breast cancer cell lines. Breast Cancer Res Treat. 2009; 118:293-305. 
156. Bouatia-Naji N, Bonnefond A, Cavalcanti-Proenca C, Sparso T, Holmkvist J, Marchand M, Delplanque J, Lobbens S, Rocheleau G, Durand E, De Graeve F, Chevre JC, Borch-Johnsen K, et al. A variant near MTNR1B is associated with increased fasting plasma glucose levels and type 2 diabetes risk. Nat Genet. 2009; 41:89-94.

157. Li C, Shi Y, You L, Wang L, Chen ZJ. Melatonin receptor 1A gene polymorphism associated with polycystic ovary syndrome. Gynecol Obstet Invest. 2011; 72:130-134.

158. Lyssenko V, Nagorny CL, Erdos MR, Wierup N, Jonsson A, Spegel P, Bugliani M, Saxena R, Fex M, Pulizzi N, Isomaa B, Tuomi T, Nilsson P, et al. Common variant in MTNR1B associated with increased risk of type 2 diabetes and impaired early insulin secretion. Nat Genet. 2009; 41:82-88.

159. Prokopenko I, Langenberg C, Florez JC, Saxena R, Soranzo N, Thorleifsson G, Loos RJ, Manning AK, Jackson AU, Aulchenko Y, Potter SC, Erdos MR, Sanna S, et al. Variants in MTNR1B influence fasting glucose levels. Nat Genet. 2009; 41:77-81.

160. Yang P, Liu H, Lin J, Yang H. The Association of rs4753426 Polymorphism in the Melatonin Receptor 1B (MTNR1B) Gene and Susceptibility to Adolescent Idiopathic Scoliosis: A Systematic Review and Meta-analysis. Pain Physician. 2015; 18:419-431.

161. Deming SL, Lu W, Beeghly-Fadiel A, Zheng Y, Cai Q, Long J, Shu XO, Gao YT, Zheng W. Melatonin pathway genes and breast cancer risk among Chinese women. Breast Cancer Res Treat. 2012; 132:693-699.
162. Li Y, Zhou J, Wu Y, Lu T, Yuan M, Cui Y, Zhou Y, Yang G, Hong Y. Association of osteoporosis with genetic variants of circadian genes in Chinese geriatrics. Osteoporos Int. 2016; 27:1485-1492.

163. Lin FY, Lin CW, Yang SF, Lee WJ, Lin YW, Lee LM, Chang JL, Weng WC, Lin $\mathrm{CH}$, Chien MH. Interactions between environmental factors and melatonin receptor type 1A polymorphism in relation to oral cancer susceptibility and clinicopathologic development. PLoS One. 2015; 10:e 0121677 .

164. Escames G, Acuna-Castroviejo D, Lopez LC, Tan DX, Maldonado MD, Sanchez-Hidalgo M, Leon J, Reiter RJ. Pharmacological utility of melatonin in the treatment of septic shock: experimental and clinical evidence. J Pharm Pharmacol. 2006; 58:1153-1165.

165. Lissoni P, Barni S, Cattaneo G, Tancini G, Esposti G, Esposti D, Fraschini F. Clinical results with the pineal hormone melatonin in advanced cancer resistant to standard antitumor therapies. Oncology. 1991; 48:448-450.

166. Altun A, Ugur-Altun B. Melatonin: therapeutic and clinical utilization. Int J Clin Pract. 2007; 61:835-845. 